\title{
Asymmetric Catalysis in Aqueous Media: Use of Metal-Chiral Crown Ethers as Efficient Chiral Lewis Acid Catalysts in Asymmetric Aldol Reactions
}

\author{
Shu,- Kobayashi*, Tomoaki Hamada, Satoshi Nagayama and Kei Manabe \\ Graduate School of Pharmaceutical Sciences, The University of Tokyo, Hongo, Bunkyo-ku, Tokyo 113-0033 Japan
}

\begin{abstract}
Complexos entre metal e éter de coroa quiral foram desenvolvidos como catalisadores do tipo ácido de Lewis quirais eficientes para reações aldólicas assimétricas entre éteres enólicos de silício e aldeídos em meio aquoso. Apesar de muitas reações assimétricas e catalíticas excelentes terem sido desenvolvidas recentemente, a maioria precisa ser conduzida em solventes orgânicos sob condições rigorosamente anidras. Isto se deve provavelmente à instabilidade de muitos catalisadores e/ou intermediários na presença de pequena quantidade de água. Para abordar esse ponto, procurouse avaliar complexos entre metal e éter de coroa com base na hipótese de "multi-coordenação" e verificou-se que catalisadores a base de chumbo(II) e lantanídeo(III) funcionam bem como ácidos de Lewis quirais em meio aquoso. Em nosso conhecimento, estes são os primeiros exemplos de ácidos de Lewis quirais baseados em éter de coroa que podem ser usados com sucesso em reações catalíticas e assimétricas. Os catalisadores foram caracterizados por difração de raio-X e suas estruturas únicas como catalisadores quirais foram descritas. O uso de água como solvente é essencial nessas reações de catálise assimétrica e o papel da água para explicar a alta reatividade e seletividade foi sugerido. Outro ponto importante é que os estudos cinéticos mostraram a possibilidade de que esses tipos de complexos de éter de coroa sejam adequados como catalisadores quirais em meio aquoso. Adicionalmente, embora as reações aldólicas catalíticas e assimétricas sejam uma das metodologias de formação de ligação carbono-carbono mais poderosas e vários exemplos de sucesso tenham sido relatados, o uso de solventes apróticos e anidros e de baixas temperaturas de reação $\left(-78^{\circ} \mathrm{C}\right)$ é necessário na maioria dos casos bem sucedidos. Por outro lado, as reações descritas neste trabalho ocorrem suavemente na faixa de $-10-0{ }^{\circ} \mathrm{C}$ em soluções águaalcool mantendo altos níveis de diastereo- e enantiosseletividades.
\end{abstract}

Metal-chiral crown ether complexes have been developed as efficient chiral Lewis acid catalysts for asymmetric aldol reactions of silyl enol ethers with aldehydes in aqueous media. While many excellent catalytic asymmetric reactions have been developed recently, most of them have to be carried out under strictly anhydrous conditions in organic solvents. This is probably due to the instability of many catalysts and/or intermediates in the presence of even a small amount of water. To address this issue, we searched for metal-crown ether complexes on the basis of our "multicoordination" hypothesis, and found that lead(II) and lanthanide(III) catalysts worked well as chiral Lewis acids in aqueous media. To the best of our knowledge, these are the first examples of chiral crown-based Lewis acids that can be successfully used in catalytic asymmetric reactions. The catalysts have been characterized by X-ray diffraction, and their unique structures as chiral catalysts have been revealed. Use of water as a solvent is essential in these asymmetric catalysis, and the role of water on these reactions to explain the high reactivity and selectivity has been suggested. Another important point is that kinetic studies have shown the possibility that these types of crown ether complexes would be suitable as chiral catalysts employed in aqueous media. In addition, although the catalytic asymmetric aldol reactions are one of the most powerful carboncarbon bond-forming methodologies and several successful examples have been reported, the use of aprotic anhydrous solvents and low reaction temperatures $\left(-78^{\circ} \mathrm{C}\right)$ has been needed in almost all successful cases. On the other hand, the present reactions proceeded smoothly at $-10-0{ }^{\circ} \mathrm{C}$ in water-alcohol solutions while retaining high levels of diastereo- and enantioselectivities.

\section{Introduction}

Development of catalytic asymmetric reactions, especially catalytic enantioselective carbon-carbon bond-forming reactions, in aqueous media is a very difficult, but at the same time, a very challenging task for organic chemists. Due to the increasing importance of optically active compounds ${ }^{1}$, several excellent chiral catalysts have been developed recently.

* e-mail: skobayas@mol.f.u-tokyo.ac.jp 
However, most of them have to be used in strictly anhydrous organic solvents ${ }^{2}$. This is probably due to the instability of many catalysts and/or intermediates in the presence of even a small amount of water. To address this issue, we have continued fundamental research on organic reactions in aqueous media ${ }^{3}$. In this paper, we report two successful examples of catalytic asymmetric aldol reactions in aqueous media, by using lead(II) and lanthanide(III) catalysts ${ }^{4}$.

In 1991, we reported the first example of $\mathrm{Yb}(\mathrm{OTf})_{3}-$ -catalyzed aldol reactions of silyl enol ethers with formaldehyde in aqueous $\mathrm{THF}^{3 a}$. Since then, lanthanide trifluoromethanesulfonates (lanthanide triflates, $\operatorname{Ln}(\mathrm{OTf})_{3}$ ) have been used for numerous reactions including carboncarbon bond-forming reactions and other transformations. While Lewis acid-catalyzed reactions are one of the most powerful methods in modern synthetic chemistry ${ }^{5}$ and many Lewis acids have been developed so far, Ln(OTf) ${ }_{3}$ have received much attention because of their strong Lewis acidity and unique properties ${ }^{6}$. In particular, their water-tolerance nature has led to development of Lewis acid-catalyzed reactions in aqueous media ${ }^{3,7}$. These reactions have a great advantage compared with conventional Lewis acid-mediated reactions in dry organic solvents, because tedious procedures to remove water from the solvents, substrates, and catalysts are not necessary. Furthermore, $\operatorname{Ln}(\mathrm{OTf})_{3}$ can be easily recovered after the reaction is completed, and reused.

However, catalytic asymmetric reactions using Ln(OTf) in aqueous solvents have not been reported ${ }^{8-10}$. Catalytic asymmetric aldol reactions are one of the most powerful carbon-carbon bond-forming methodologies that afford synthetically useful chiral $\beta$-hydroxy ketones and esters. Chiral Lewis acid-catalyzed reactions of silyl enol ethers with aldehydes (the Mukaiyama reaction) ${ }^{11}$ are among the most convenient and promising, and several successful examples have been reported since the first chiral tin(II)catalyzed reactions appeared in $1990^{12}$. However, the use of aprotic anhydrous solvents as well as low reaction temperatures $\left(-78{ }^{\circ} \mathrm{C}\right)$ has been needed in almost all successful cases ${ }^{13}$.

\section{Results and Discussion}

In order to perform catalytic asymmetric aldol reactions successfully in aqueous media, two problems to be addressed were assumed. First, many cations (Lewis acids) hydrolyze very easily in water. To overcome this problem, we screened various cations, and have found that rare earths and some other cations such as $\mathrm{Fe}^{2+}, \mathrm{Cu}^{2+}, \mathrm{Zn}^{2+}, \mathrm{Cd}^{2+}$, and $\mathrm{Pb}^{2+}$ are stable and work as Lewis acid catalysts in water ${ }^{3 \mathrm{~g}}$. The second issue is the instability of chiral ligandcoordinated metal complexes in water. Since many chiral ligand-coordinated metal complexes are decomposed rapidly in water, we decided to utilize "multi-coordination" system and to select chiral crown ethers as chiral ligands.

Chiral crown ethers 1-4 were synthesized according to the literature methods $s^{14,15}$, and combination with metals was examined based on ionic diameters of cations ${ }^{16}$ and the hole size of the crown ethers ${ }^{14,17}$. Chiral catalysts were prepared by mixing metal compounds and the crown ethers, and were tested in a model aldol reaction of the (Z)-silyl enol ether of propiophenone (5) with benzaldehyde in water-ethanol (1:9) at $0{ }^{\circ} \mathrm{C}$. The results are summarized in Table 1 . When $\mathrm{Cu}(\mathrm{OTf})_{2}$ or $\mathrm{Zn}(\mathrm{OTf})_{2}$ was combined with $\mathbf{1}^{18}$, the aldol reaction proceeded smoothly to afford the corresponding adduct in high yield albeit no chiral induction was observed. According to the diameters and the hole size, we next examined the combination of $\mathrm{Sc}(\mathrm{OTf})_{3}$ or $\mathrm{Yb}(\mathrm{OTf})_{3}$ and $\mathbf{2}^{19}$, and it was also found that no chiral induction was detected in the model aldol reaction. We then studied the use of AgOTf or $\mathrm{Pb}(\mathrm{OTf})_{2}$ and $\mathbf{3}^{20}$. While low chiral induction was observed using AgOTf-3, it was exciting to find that the aldol reaction proceeded smoothly using $\mathrm{Pb}(\mathrm{OTf})_{2} \mathbf{- 3}$ to afford the corresponding adduct in $62 \%$ yield with high syn-selectivity (syn/anti $=$ 90/10) and that the enantiomeric excess (ee) of the synadduct was $55 \%(2 S, 3 S)^{21}$. It should be noted that the hole size of the crown ether was essential because no chiral induction was observed in the same model aldol reaction using the combination of $\mathrm{Pb}(\mathrm{OTf})_{2}$ and $\mathbf{1}$ or $\mathbf{2}$. It was also found that the counter anions of lead(II) strongly influenced the selectivity. While the same level of enantioselectivity was obtained by using $\mathrm{Pb}\left(\mathrm{ClO}_{4}\right)_{2}$ and $\mathbf{3}$, lower enantiomeric excesses were observed when $\mathrm{Pb}\left(\mathrm{NO}_{3}\right)_{2}$ or $\mathrm{Pb}\left(\mathrm{SbF}_{6}\right)_{2}$ and 3 were used. When $\mathrm{Pb}\left(\mathrm{BF}_{4}\right)_{2}, \mathrm{~Pb}\left(\mathrm{PF}_{6}\right)_{2}$, or $\mathrm{PbF}_{2}$ was employed, the model aldol reactions proceeded sluggishly.

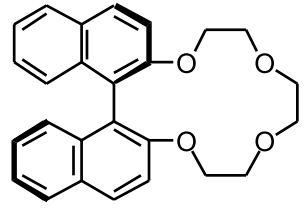

1

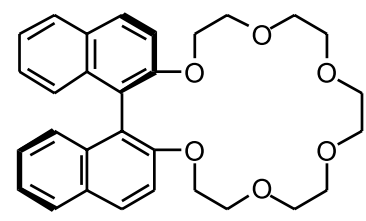

3

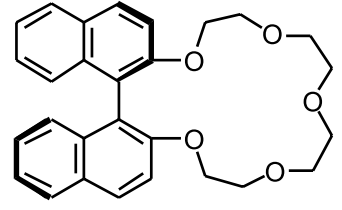

2

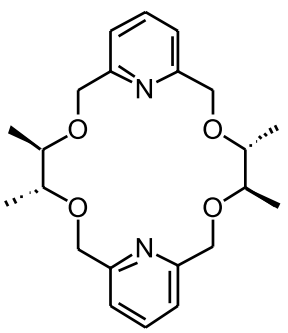


Table 1. Effect of Metal-Ligand Combinations

\begin{tabular}{|c|c|c|c|c|}
\hline \multirow{2}{*}{$\begin{array}{l}\mathrm{PhCHO} \\
\mathrm{MXn}\end{array}$} & \multirow{2}{*}{ Ligand } & \multicolumn{2}{|c|}{$\begin{array}{l}\begin{array}{l}\mathrm{MXn}(20 \mathrm{~mol} \%) \\
+ \text { Ligand }(24 \mathrm{~mol} \%)\end{array} \\
\underset{\begin{array}{c}\mathrm{H}_{2} \mathrm{O} / \mathrm{EtOH}=1 / 9 \\
0\end{array}{ }^{\circ} \mathrm{C}, 18-24 \mathrm{~h}}{\longrightarrow}\end{array}$} & \multirow[b]{2}{*}{ ee $(\%)^{a}$} \\
\hline & & Yield (\%) & syn/anti & \\
\hline $\mathrm{Zn}(\mathrm{OTf})_{2}$ & 1 & 88 & $69 / 31$ & 2 \\
\hline $\mathrm{Cu}(\mathrm{OTf})_{2}$ & 1 & 86 & $87 / 13$ & 0 \\
\hline $\mathrm{Sc}(\mathrm{OTf})_{3}$ & 2 & 75 & $52 / 48$ & 1 \\
\hline $\mathrm{Yb}(\mathrm{OTf})_{3}$ & 2 & 74 & $63 / 37$ & 1 \\
\hline AgOTf & 3 & 61 & $75 / 25$ & 5 \\
\hline $\mathrm{Pb}(\mathrm{OTf})_{2}$ & 3 & 62 & $90 / 10$ & 55 \\
\hline $\mathrm{Pb}(\mathrm{OTf})_{2}$ & 1 & 78 & $89 / 11$ & 0 \\
\hline $\mathrm{Pb}(\mathrm{OTf})_{2}$ & 2 & 92 & $89 / 11$ & 0 \\
\hline $\mathrm{Sc}(\mathrm{OTf})_{3}$ & 4 & 86 & $91 / 39$ & 0 \\
\hline $\mathrm{Y}(\mathrm{OTf})_{3}$ & 4 & 95 & $55 / 45$ & 7 \\
\hline $\mathrm{La}(\mathrm{OTf})_{3}$ & 4 & 88 & $86 / 14$ & 79 \\
\hline $\mathrm{Ce}(\mathrm{OTf})_{3}$ & 4 & 78 & $93 / 7$ & 82 \\
\hline $\operatorname{Pr}(\mathrm{OTf})_{3}$ & 4 & 90 & $90 / 10$ & 79 \\
\hline $\mathrm{Nd}(\mathrm{OTf})_{3}$ & 4 & 85 & $93 / 7$ & 75 \\
\hline $\mathrm{Sm}(\mathrm{OTf})_{3}$ & 4 & 50 & $89 / 11$ & 55 \\
\hline $\mathrm{Eu}(\mathrm{OTf})_{3}$ & 4 & 58 & $89 / 11$ & 51 \\
\hline $\mathrm{Gd}(\mathrm{OTf})_{3}$ & 4 & 49 & $78 / 22$ & 41 \\
\hline $\mathrm{Tb}(\mathrm{OTf})_{3}$ & 4 & 78 & $77 / 23$ & 27 \\
\hline Dy $(\mathrm{OTf})_{3}$ & 4 & 87 & $63 / 37$ & 9 \\
\hline $\mathrm{Ho}(\mathrm{OTf})_{3}$ & 4 & 87 & $56 / 44$ & 3 \\
\hline $\mathrm{Yb}(\mathrm{OTf})_{3}$ & 4 & 78 & $89 / 11$ & 0 \\
\hline
\end{tabular}

${ }^{\mathrm{a} E e}$ of syn-adduct.

On the other hand, chiral crown ether $\mathbf{4}$ combined with $\mathrm{Ln}(\mathrm{OTf})_{3}$ was found to be effective. For example, when 4 $(12 \mathrm{~mol} \%)$ and $\operatorname{Pr}(\mathrm{OTf})_{3}(10 \mathrm{~mol} \%)$ were used, the reaction of benzaldehyde with silyl enol ether 5 in water/ethanol (1:9) at $0{ }^{\circ} \mathrm{C}$ for $18 \mathrm{~h}$ gave the desired aldol adduct in high yield $(85 \%)$ with high diastereo- $($ syn/anti $=91 / 9)$ and enantioselectivities ( $78 \%$ ee for the $s y n$ isomer $(2 R, 3 R))$. Also in this case, the ionic diameters ${ }^{16}$ significantly affected the selectivity ${ }^{22}$. For the larger cations such as $\mathrm{La}, \mathrm{Ce}, \mathrm{Pr}$, and $\mathrm{Nd}$, both diastereo- and enantioselectivities were high, while the smaller cations such as $\mathrm{Sc}$ and $\mathrm{Yb}$ showed no enantioselection.

In addition, it was revealed in these reactions that water played an essential role for the high yields and selectivities. The effect of solvents on yields in the chiral lead (II)catalyzed aldol reaction is summarized in Table 2 . The aldol reaction proceeded most efficiently in a water-alcohol solution. 2-Propanol was the best alcohol, and much lower yield and selectivities were obtained when the reaction was carried out in dichloromethane. In pure water (without alcohols), lower yield and selectivities were also observed, while the diastereo- and selectivities were improved in the presence of a surfactant ${ }^{23}$. On the other hand, when chiral $\operatorname{Pr}(\mathrm{III})$-catalyzed aldol reaction of benzaldehyde with $\mathbf{5}$ was carried out in pure ethanol, lower yield and selectivity were observed $(51 \%$ yield $(16 \mathrm{~h})$, syn/anti $=85 / 15,23 \%$ ee for the $s y n$ isomer $(2 R, 3 R))^{24}$. Furthermore, the reaction in dichloromethane resulted in much lower yield and selectivity $(3 \%$ yield $(185 \mathrm{~h})$, syn/anti $=64 / 36,22 \%$ ee $)$.

Table 2. Effect of Solvents

\begin{tabular}{|c|c|c|c|}
\hline $\mathrm{PhCHO}+\overbrace{\mathrm{Ph}}^{\mathrm{OSiMe}_{3}}$ & $\begin{array}{r}\mathrm{Pb}(\mathrm{OTf}) \\
+3(24 \mathrm{n} \\
0^{\circ} \mathrm{Co}\end{array}$ & (\%) & 1 \\
\hline Solvent & Yield (\%) & syn/anti & ee $(\%)^{\mathrm{a}}$ \\
\hline $\mathrm{H}_{2} \mathrm{O} / \mathrm{EtOH}=1 / 9$ & 62 & $90 / 10$ & 62 \\
\hline $\mathrm{H}_{2} \mathrm{O} / \mathrm{EtOH}=1 / 4.5$ & 92 & $88 / 12$ & 57 \\
\hline $\mathrm{H}_{2} \mathrm{O} / \mathrm{EtOH}=1 / 1$ & 19 & $87 / 13$ & 53 \\
\hline $\mathrm{H}_{2} \mathrm{O} / 2-\mathrm{PrOH}=1 / 9$ & 92 & $91 / 9$ & 62 \\
\hline $\mathrm{H}_{2} \mathrm{O} / 2-\mathrm{PrOH}=1 / 4.5$ & 89 & $91 / 9$ & 69 \\
\hline $\mathrm{H}_{2} \mathrm{O} /$ tert $-\mathrm{BuOH}=1 / 9$ & 76 & $89 / 11$ & 62 \\
\hline $\mathrm{H}_{2} \mathrm{O}$ & 4 & $70 / 30$ & 15 \\
\hline $\mathrm{H}_{2} \mathrm{O}-\mathrm{SDS}(35 \mathrm{mM})$ & 20 & $89 / 11$ & 56 \\
\hline $\mathrm{CH}_{2} \mathrm{Cl}_{2}$ & 10 & $80 / 20$ & $8^{\mathrm{b}}$ \\
\hline
\end{tabular}

${ }^{\mathrm{a}} \mathrm{Ee}$ of syn-adduct. ${ }^{\mathrm{b}}$ Reverse enantioselectivity was observed.

Other substrates were then tested in these systems $\left(\mathrm{Pb}(\mathrm{OTf})_{2}-\mathbf{3}, 20 \mathrm{~mol} \%\right.$, water-2-propanol (1:4.5), $0{ }^{\circ} \mathrm{C}$; $\operatorname{Pr}(\mathrm{OTf})_{3}-\mathbf{4}, 10 \mathrm{~mol} \%$, water-ethanol (1:9), $\left.-10^{\circ} \mathrm{C}\right)$. As shown in Table 3, most reactions proceeded smoothly in the aqueous media to afford the desired aldol adducts in good to high yields with good to high diastereo- and enantioselectivities. It should be noted that high yields and high levels of diastereo- and enantioselectivities were attained at $-15-0{ }^{\circ} \mathrm{C}$ in aqueous media, and that even aliphatic aldehydes worked well under these reaction conditions. In addition, it is noteworthy that $\mathrm{Pb}(\mathrm{OTf})_{2}$ and $\operatorname{Pr}(\mathrm{OTf})_{3}$ can be easily recovered after extraction of organic materials from the aqueous layer with an organic solvent and evaporation of water. Ligand $\mathbf{3}$ and $\mathbf{4}$ were easily separated from other organic products by silica gel chromatography.

Table 3. Catalytic Asymmetric Aldol Reactions in Aqueous Media

\begin{tabular}{|c|c|c|c|c|c|}
\hline \multirow{2}{*}{$\begin{array}{r}\mathrm{R}^{1} \mathrm{CHO} \\
\mathrm{R}^{1}\end{array}$} & \multirow{2}{*}{$\underbrace{\mathrm{OSiMe}_{3}}_{\mathrm{R}^{2}}$} & \multicolumn{2}{|c|}{$\frac{\text { Catalyst }}{\mathrm{H}_{2} \mathrm{O} / \mathrm{ROH}}$} & | & \multirow[b]{2}{*}{ ee $(\%)^{\mathrm{a}}$} \\
\hline & & Catalyst $^{\mathrm{b}}$ & Yield (\%) & syn/anti & \\
\hline $\mathrm{Ph}$ & $\mathrm{Ph}$ & $\mathbf{A}$ & 89 & $91 / 9$ & 69 \\
\hline $\mathrm{p}-\mathrm{ClPh}$ & $\mathrm{Ph}$ & $\mathbf{A}$ & 74 & $82 / 18$ & 62 \\
\hline $\mathrm{C}_{5} \mathrm{H}_{11}$ & $\mathrm{Ph}$ & $\mathbf{A}$ & 82 & $92 / 8$ & 80 \\
\hline $\mathrm{C}_{8} \mathrm{H}_{17}$ & $\mathrm{Ph}$ & $\mathbf{A}$ & 79 & $90 / 10$ & 82 \\
\hline$\left(\mathrm{CH}_{3}\right)_{2} \mathrm{CHCH}_{2}$ & $\mathrm{Ph}$ & $\mathbf{A}$ & $99(88)$ & $94 / 6(93 / 7)$ & $87(85)^{c}$ \\
\hline$\left(\mathrm{CH}_{3}\right)_{2} \mathrm{CH}$ & $\mathrm{Ph}$ & $\mathbf{A}$ & 65 & $90 / 10$ & 78 \\
\hline 2-Thienyl & $\mathrm{Ph}$ & $\mathbf{A}$ & 67 & $90 / 10$ & 75 \\
\hline $\mathrm{Ph}$ & SEt & $\mathbf{A}$ & 51 & $93 / 7$ & 47 \\
\hline$p$-MeOPh & $\mathrm{Ph}$ & B & 83 & $93 / 7$ & 75 \\
\hline 1-Nap & $\mathrm{Ph}$ & B & 92 & $88 / 12$ & 72 \\
\hline $\mathrm{PhCH}=\mathrm{CH}$ & $\mathrm{Ph}$ & B & 77 & $78 / 22$ & 76 \\
\hline $\mathrm{Ph}\left(\mathrm{CH}_{2}\right)_{2}$ & $\mathrm{Ph}$ & B & 53 & $67 / 33$ & 47 \\
\hline $\mathrm{Ph}$ & Et & B & 53 & $81 / 19$ & 68 \\
\hline $\mathrm{Ph}$ & $\mathrm{S} t-\mathrm{Bu}$ & B & 33 & $93 / 7$ & 73 \\
\hline
\end{tabular}

${ }^{\mathrm{a} E e}$ of syn-adduct. ${ }^{\mathrm{b}} \mathbf{A}: \mathrm{Pb}(\mathrm{OTf})_{2} \mathbf{- 3}(20 \mathrm{~mol} \%), 0{ }^{\circ} \mathrm{C} ; \mathbf{B}: \operatorname{Pr}(\mathrm{OTf})_{3}-\mathbf{4}(10$ mol \%), $-10{ }^{\circ} \mathrm{C} .{ }^{\mathrm{c}} 10 \mathrm{~mol} \%$. 
The observed selectivities suggest that, in the case of $\mathrm{Pb}, \mathrm{La}, \mathrm{Ce}, \mathrm{Pr}$, and $\mathrm{Nd}$, only a negligible amount of metal cations which are uncomplexed with $\mathbf{3}$ or $\mathbf{4}$ exists in water/ ethanol (1/9). ${ }^{1} \mathrm{H}$ NMR studies revealed the strong binding of $\mathbf{4}$ to La cations. In spite of the strong binding of $\mathbf{4}$ to lanthanide cations such as La and Pr, 4 was found not to reduce their activity to a significant extent. Figure 1 shows the reaction profiles for the aldol reaction in the presence and absence of $\mathbf{4}$. It should be noted that, although $\mathbf{4}$ slightly decelerated the reaction, sufficient reactivity still remained in the presence of $\mathbf{4}$. This result is surprising because increase of the electron density of Pr by coordination of the two pyridine nitrogens of $\mathbf{4}$ seems to deactivate $\operatorname{Pr}(\mathrm{OTf})_{3}$ significantly. Thus, the retention of the Lewis acidity is the key to realize the asymmetric induction in the present $\mathrm{Ln}(\mathrm{OTf})_{3}$-catalyzed aldol reactions ${ }^{25}$. On the other hand, a similar remarkable result was obtained in the chiral lead (II)-catalyzed aldol reaction. A kinetic study was performed in the following two systems: $\mathrm{Pb}(\mathrm{OTf})_{2}$-3-cataltzed aldol reaction in water-ethanol $(1: 4.5)$ and $\mathrm{Pb}(\mathrm{OTf})_{2}$-catalyzed achiral reaction in the same solvent system (Figure 2$)^{14}$. It was remarkable to find that almost comparable reaction rates between the above two systems were observed. In addition, the same levels of diastereo- and enantioselectivities were obtained during the reaction course in the $\mathrm{Pb}(\mathrm{OTf})_{2}-\mathbf{3}$-catalyzed reactions. These results also indicate that suitable combinations of metal-chiral crown ether complexes provide promising chiral catalysts in aqueous media.

The key to these catalytic asymmetric aldol reactions is novel chiral lead (II) and lanthanide(III) catalysts. The solid state structure of $\mathrm{Pb}(\mathrm{OTf})_{2}-3$ was determined by single-crystal X-ray diffraction (Figure 3$)^{26}$. The lead atom

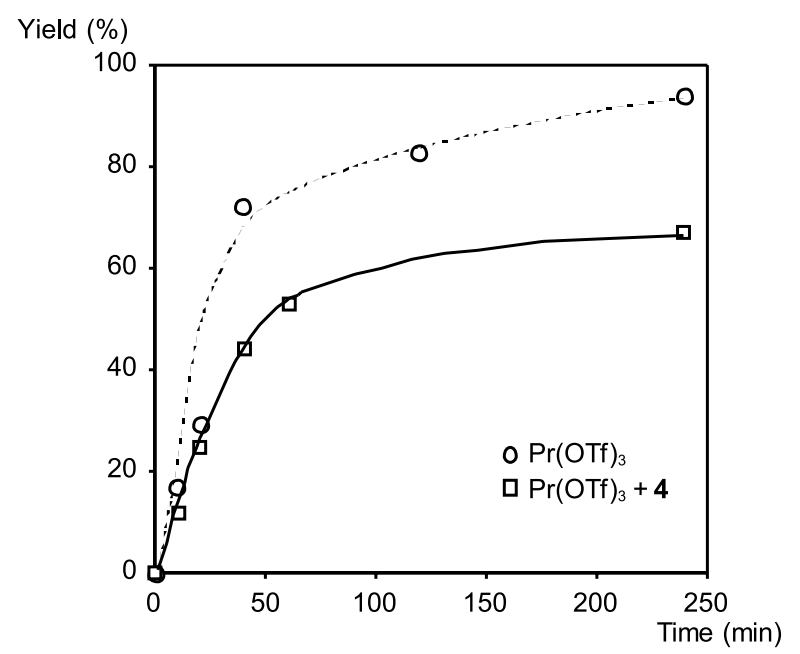

Figure 1. Reaction profiles for the $\operatorname{Pr}(\mathrm{OTf})_{3}$-catalyzed aldol reaction of benzaldehyde with 5 in water/ethanol $(1 / 9)$ at $0{ }^{\circ} \mathrm{C}$ in the absence and presence of 4 . is coordinated by the six oxygens of the crown ether, two triflates, and one water. A characteristic point is that one $\mathrm{Pb}-\mathrm{O}$ bond $(310.9 \mathrm{pm})$ is much longer than others ${ }^{27}$. The oxygen atom is directly connected to the binaphthyl ring of $\mathbf{3}$, and the long length is ascribed to the dihedral angle between the two naphthalene rings of $\mathbf{3}$, which create an excellent asymmetric environment in the lead (II) catalyst. The high selectivities obtained would be explained by assuming that the water coordinating to lead (II) is replaced by aldehydes under the reaction conditions ${ }^{3 \mathrm{~g}}$, and that silyl enolates attack the aldehydes to afford the $(2 S, 3 S)$-adduct.

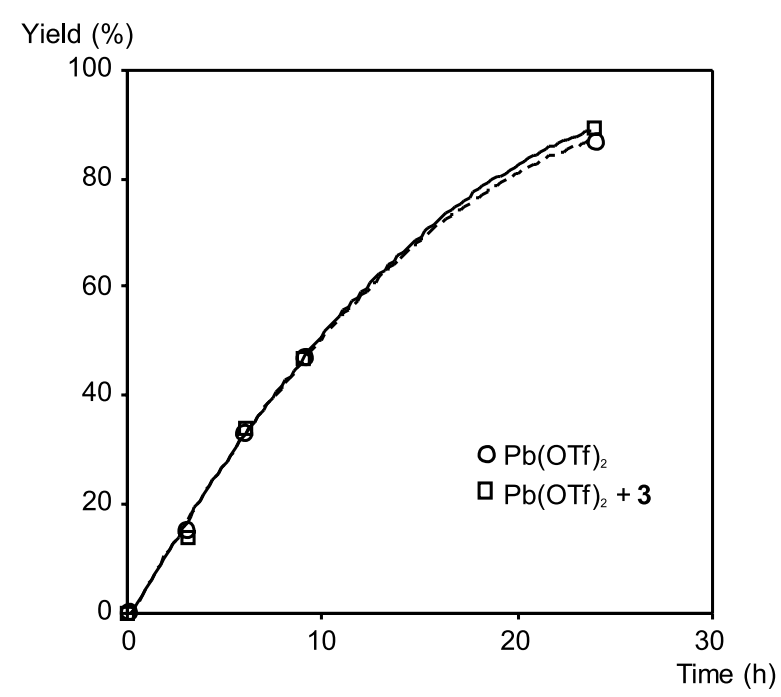

Figure 2. Reaction profiles for the $\mathrm{Pb}(\mathrm{OTf})_{2}$-catalyzed aldol reaction of benzaldehyde with 5 in water/ethanol (1/9) at $0{ }^{\circ} \mathrm{C}$ in the absence and presence of $\mathbf{3}$.

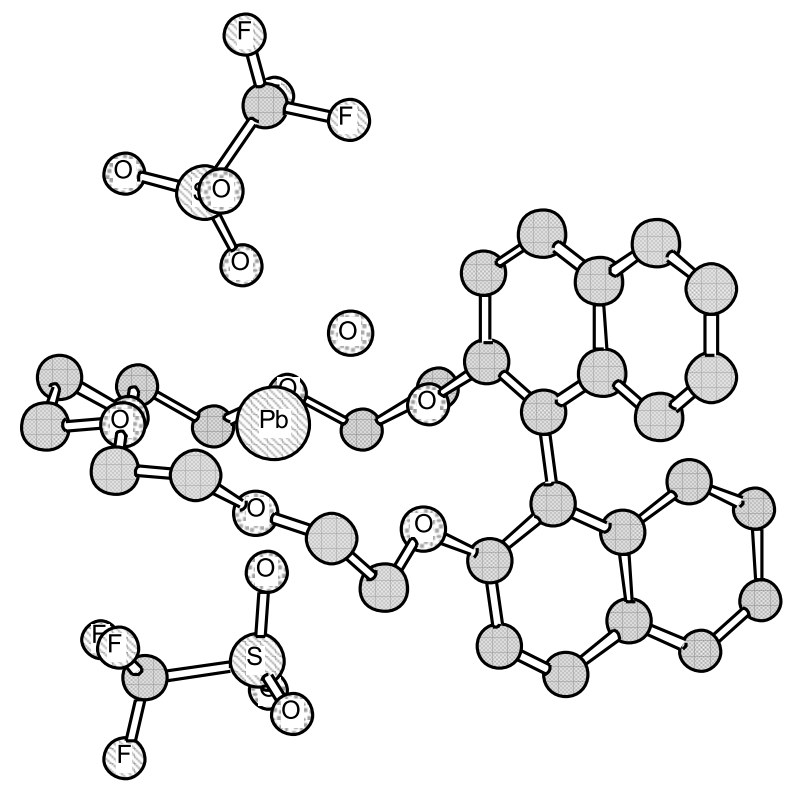

Figure 3. $\mathrm{Pb}(\mathrm{OTf})_{2}$-crown ether $\mathbf{3}$ (X-ray). Hydrogen atoms are omitted for clarity. 


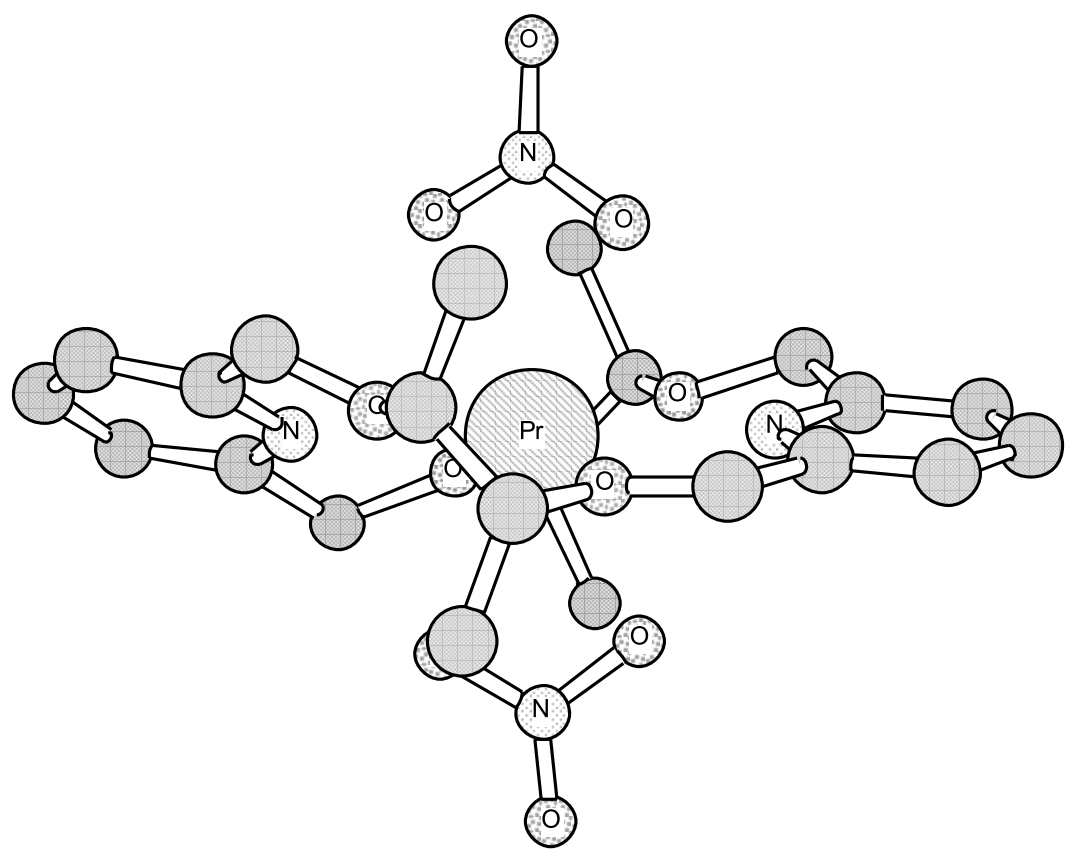

Figure 4. $\left.\left[\operatorname{Pr}\left(\mathrm{NO}_{3}\right)_{2}\right)^{+4}\right]^{+}$moiety in $\mathrm{X}$-ray structure of $\left[\operatorname{Pr}\left(\mathrm{NO}_{3}\right)_{2} \bullet 4\right]_{3}\left[\operatorname{Pr}\left(\mathrm{NO}_{3}\right)_{6}\right]$. Hydrogen atoms are omitted for clarity.

On the other hand, an X-ray crystal structure of the $\mathrm{Pr}$ cation and 4 was obtained for $\left[\operatorname{Pr}\left(\mathrm{NO}_{3}\right)_{2} \cdot 4\right]_{3}\left[\operatorname{Pr}\left(\mathrm{NO}_{3}\right)_{6}\right]$ (Figure 4$)^{28}$. In this structure, a single structure for the complex of Pr with 4 was observed. The Pr cation complexed with 4 is located almost in the plane of the crown ring. Interestingly, the methyl groups of $\mathbf{4}$ are all in axial positions ${ }^{29}$. We assume that this conformation of the crown ring is crucial to create an effective chiral environment around the Pr cation. It is also likely that one or two of the nitrate anions are dissociated in aqueous media, and that aldehydes to be activated coordinate in place of the nitrate anion.

In summary, we have developed $\mathrm{Pb}(\mathrm{OTf})_{2}$-crown ether 3 and $\operatorname{Ln}(\mathrm{OTf})_{3}$-crown ether $\mathbf{4}$ as efficient chiral catalysts for asymmetric aldol reactions in aqueous media. To the best of our knowledge, these are the first examples of chiral crown-based Lewis acids ${ }^{30}$ that can be successfully used in catalytic asymmetric reactions. It should be noted that the novel chiral catalysts were successfully used in aqueous media. These reaction systems do not need vigorous drying of the substrates and the catalysts, and $\mathrm{Pb}(\mathrm{OTf})_{2}$ and $\mathrm{Ln}(\mathrm{OTf})_{3}$ can be easily recovered. Our strategy is based on the size-fitting effects of macrocyclic ligands. In fact, slight changes in ionic diameters of the metal cations greatly affected the diastereo- and enantioselectivities of the aldol adducts. The catalysts have been characterized by X-ray diffraction, and their unique structures as chiral catalysts have been revealed. Kinetic studies have shown potential utility of these types of chiral catalysts which can be employed in aqueous media. Although the stereoselectivity remains to be improved further, the present work will provide a useful concept for the design of chiral catalysts which function effectively in aqueous media.

\section{Experimental}

Typical experimental procedure for the catalytic asymmetric aldol reactions using $\mathrm{Pb}(\mathrm{OTf})_{2}-\mathbf{3}$.

To a water-2-propanol (1:4.5) solution $(0.5 \mathrm{~mL})$ of $\mathrm{Pb}(\mathrm{OTf})_{2}-3$ (20 mol\%) was added an aldehyde $(0.5 \mathrm{mmol})$ and a silyl enol ether $(0.75 \mathrm{mmol})$ in water-2-propanol (1:4.5, $1.0 \mathrm{~mL}$ ) at $0{ }^{\circ} \mathrm{C}$. After the mixture was stirred for $20 \mathrm{~h}$ at the same temperature, water $(10 \mathrm{~mL})$ and ethyl acetate $(15 \mathrm{~mL})$ were added. The organic layer was separated and the aqueous layer was extracted with ethyl acetate. $\mathrm{Pb}(\mathrm{OTf})_{2}$ was recovered from the aqueous layer quantitatively after removing water. For the organic layer, the combined organic materials were dried over $\mathrm{Na}_{2} \mathrm{SO}_{4}$. After a usual work-up, the crude product was purified by column chromatography on silica gel to afford the corresponding aldol product. Chiral crown ether 3 was also recoverable by the column chromatography. The diastereomers were separated, and the enantiomeric excess was determined by HPLC analysis using a chiral column. When the diastereomer separation by column chromatography was difficult, the diastereomer ratio was determined by ${ }^{1} \mathrm{H}$ NMR analysis. 
Typical experimental procedure for the catalytic asymmetric aldol reactions using $\operatorname{Ln}(\mathrm{OTf})_{3}-\mathbf{4}$.

To a solution of $\operatorname{Ln}(\mathrm{OTf})_{3}(10-20 \mathrm{~mol} \%)$ in water/ ethanol $(1 / 9,0.1 \mathrm{~mL})$ at 0 or $-10{ }^{\circ} \mathrm{C}$ was added a solution of 4 (12-24 mol \%) in water/ethanol (1/9, $0.4 \mathrm{~mL})$. Then, a solution of an aldehyde $(0.2 \mathrm{mmol})$ in water/ethanol $(1 / 9,0.3 \mathrm{~mL})$ and a solution of a silyl enol ether $(0.3 \mathrm{mmol})$ in water/ethanol $(1 / 9,0.3 \mathrm{~mL})$ was added. The whole was stirred for $18 \mathrm{~h}$ at the same temperature. The reaction was quenched by addition of aq. $\mathrm{NaHCO}_{3}$. The mixture was extracted with dichloromethane three times, dried over $\mathrm{Na}_{2} \mathrm{SO}_{4}$, and concentrated. The desired product was purified by silica gel chromatography (AcOEt/hexane 1/6).

For the recovery of $\mathrm{Ln}(\mathrm{OTf})_{3}$ and 4, the following workup procedure was used: After the aldol reaction was completed, water $(10 \mathrm{~mL})$ was added. The organic materials were extracted with dichloromethane three times, and the combined organic layers were washed with water, dried over $\mathrm{Na}_{2} \mathrm{SO}_{4}$, concentrated, and purified by silica gel chromatography. The Ln(OTf) 3 used was recovered by concentration of the combined aqueous layers and drying in vacuo at $150{ }^{\circ} \mathrm{C}$.

\section{References}

1. Jacobsen, E. N.; Pfaltz, A.; Yamamoto, H. Eds. Comprehensive Asymmetric Catalysis, Springer: Heidelberg, 1999.

2. a) Grieco, P. Ed. Organic Reactions in Water, Chapman \& Hall, 1998; b) Li, C.-J.; Chan, T.-H. Organic Reactions in Aqueous Media, Wiley: New York, 1997; c) Lubineau, A.; Augé, J.; Queneau, Y. Synthesis 1994, 741; d) Li, C.-J. Chem. Rev. 1993, 93, 2023; e) Reissig, H.-U. In Organic Synthesis Highlights, Waldmann, H. Ed. VCH: Weinheim, 1991, p 71; f) Einhorn, C.; Einhorn, J.; Luche, J. Synthesis 1989, 787.

3. a) Kobayashi, S. Chem. Lett. 1991, 2187; b) Hachiya, I.; Kobayashi, S. J. Org. Chem. 1993, 58, 6958; c) Kobayashi, S.; Hachiya, I. J. Org. Chem., 1994, 59, 3590; d) Kobayashi, S.; Ishitani, H. J. Chem. Soc., Chem. Commun. 1995, 1379; e) Kobayashi, S.; Wakabayashi, T.; Nagayama, S.; Oyamada, H. Tetrahedron Lett. 1997, 38, 4559; f) Kobayashi, S. In Organic Reactions in Water, Grieco, P. Ed.; Chapman \& Hall: London, 1998, p. 262; g) Kobayashi, S.; Nagayama, S.; Busujima, T. J. Am. Chem. Soc. 1998, 120, 8287; h) Manabe, K.; Mori, Y.; Kobayashi, S. Synlett 1999, 1401; i) Nagayama, S.; Kobayashi, S. Angew. Chem., Int. Ed. 2000, 39, 567; j) Mori, Y.; Manabe, K.; Kobayashi, S. Angew. Chem., Int. Ed. in press. See also Ref. 8.
4. For preliminary communications: a) Nagayama, S.; Kobayashi, S. J. Am. Chem. Soc. 2000, 122, 11531; b) Kobayashi, S.; Hamada, T.; Nagayama, S.; Manabe, K. Org. Lett. 2001, 3, 165.

5. a) Santell, M.; Pons, J.-M. Lewis Acids and Selectivity in Organic Synthesis; CRC Press: Boca Raton, 1995; b) Yamamoto, H. Ed. Lewis Acids in Organic Synthesis, Wiley-VCH: Weinheim, 2000.

6. Kobayashi, S. In Lanthanides: Chemistry and Use in Organic Synthesis; Kobayashi, S., Ed.; Springer: Berlin, 1999, pp 63.

7. a) Kobayashi, S. Synlett 1994, 689; b) Kobayashi, S.; Manabe, K.; Nagayama, S. In Modern Carbonyl Chemistry; Otera, J., Ed.; Wiley-VCH: Weinheim, 2000; c) Kobayashi, S. Eur. J. Org. Chem. 1999, 15.

8. We have recently reported $\mathrm{Cu}$ (II)-catalyzed asymmetric aldol reactions in aqueous media: a) Kobayashi, S.; Nagayama, S.; Busujima, T. Chem. Lett. 1999, 71; b) Kobayashi, S.; Nagayama, S.; Busujima, T. Tetrahedron 1999, 55, 8739; c) Kobayashi, S.; Mori, Y.; Nagayama, S.; Manabe, K. Green Chemistry 1999, 1, 175.

9. Lanthanide triflate-catalyzed enantioselective DielsAlder and 1,3-dipolar cycloaddition reactions in nonaqueous solvents have been reported: a) Kobayashi, S.; Ishitani, H. J. Am. Chem. Soc. 1994, 116, 4083; b) Kobayashi, S.; Kawamura, M. J. Am. Chem. Soc. 1998, 120, 5840; c) Markó, I. E.; Chellé-Regnaut, I.; Leroy, B.; Warriner, S. L. Tetrahedron Lett. 1997, 38, 4269; d) Sanchez-Blanco, A. I.; Gothelf, K. V.; Jørgensen, K. A. Tetrahedron Lett. 1997, 38, 7923; e) Nishida, A.; Yamanaka, M.; Nakagawa, M. Tetrahedron Lett. 1999, 40, 1555.

10. Reviews on catalytic asymmetric aldol reactions, see: a) Carreira, E. M. in Comprehensive Asymmetric $\mathrm{Ca}$ talysis; Jacobsen, E. N.; Pfaltz, A.; Yamamoto, H. Eds.; Springer-Verlag: Berlin, 1999, pp 997; b) Machajewski, T. D.; Wong, C.-H. Angew. Chem. Int. Ed. 2000, 39, 1352; c) Mahrwald, R. Chem. Rev. 1999, 99, 1095; d) Gröger, H.; Vogl, E. M.; Shibasaki, M. Chem. Eur. J. 1998, 4, 1137; e) Nelson, S. G. Tetrahedron: Asym. 1998, 9, 357; f) Bach, T. Angew. Chem., Int. Ed. Engl. 1994, 33, 417.

11. Mukaiyama, T.; Narasaka, K.; Banno, K. Chem. Lett. 1973, 1012.

12. a) Kobayashi, S.; Fujishita, Y.; Mukaiyama, T. Chem. Lett. 1990, 1455; b) Mukaiyama, T.; Kobayashi, S.; Uchiro, H.; Shiina, I. Chem. Lett. 1990, 129.

13. Some catalytic asymmetric aldol reactions were performed at higher temperatures $\left(-20-23{ }^{\circ} \mathrm{C}\right)$ : a) Mikami, K.; Matsukawa, S. J. Am. Chem. Soc. 1993, 115, 7039; b) Carreira, E. M.; Singer, R. A.; Lee, W. J. Am. Chem. Soc. 1994, 116, 8837; c) Keck, G. E.; 
Krishnamurthy, D. J. Am. Chem. Soc. 1995, 117, 2363. Catalytic asymmetric aldol reactions in wet dimethylformamide were reported: d) Sodeoka, M.; Ohrai, K.; Shibasaki, M. J. Org. Chem. 1995, 60, 2648.

14. Kyba, E. P.; Helheson, R. C.; Madan, K.; Gokel, G. W.; Tarnowski, T. L.; Moore, S. S.; Cram, D. J. J. Am. Chem. Soc. 1977, 99, 2564.

15. Bradshaw, J. S.; Huszthy, P.; McDaniel, C. W.; Zhu, C. Y.; Dalley, N. K.; Izatt, R. M.; Lifson, S. J. Org. Chem. 1990, 55, 3129.

16. a) Shannon, R. D.; Prewitt, C. T. Acta Crystallogr. 1969, B25, 925; b) Shannon, R. D. Acta Crystallogr. 1976, A32, 751.

17. Kyba, E. P.; Gokel, G. W.; de Jong, F.; Koga, K.; Sousa, L. R.; Siegel, M. G.; Kaplan, L.; Sogah, G. D. Y.; Cram, D. J. J. Org. Chem. 1977, 42, 4173.

18. Ionic diameters (coordination number $(\mathrm{CN})=6$ ) of $\mathrm{Cu}^{2+}$ and $\mathrm{Zn}^{2+}$ are $146 \mathrm{pm}$ and $148 \mathrm{pm}$, respectively ${ }^{16}$. The hole size of 12-crown-4 was reported to be 120150 pm. Vögtle, F. Supramolecular Chemistry: An Introduction, John Wiley \& Sons: Chichester, 1989.

19. Ionic diameters $(\mathrm{CN}=8)$ of $\mathrm{Sc}^{3+}$ and $\mathrm{Yb}^{3+}$ are $174 \mathrm{pm}$ and 198 pm, respectively ${ }^{16}$. The hole size of 15-crown5 was reported to be $170-220 \mathrm{pm}$.

20. Ionic diameters of $\mathrm{Ag}^{+}$and $\mathrm{Pb}^{2+}(\mathrm{CN}=8)$ are $256 \mathrm{pm}$ and $258 \mathrm{pm}$, respectively ${ }^{16}$. The hole size of 18 -crown6 was reported to be $260-320 \mathrm{pm}$.

21. The absolute configulation was determined by comparison with the authentic sample: Denmark, S. E.; Wong, K.-T.; Stavenger, R. A. J. Am. Chem. Soc. 1997, 119, 2333.

22. Size effects of lanthanides on enantioselectivity have been observed in asymmetric reactions. For example: a) Sasai, H.; Suzuki, T.; Itoh, N.; Arai, S.; Shibasaki, M. Tetrahedron Lett. 1993, 34, 2657; b) Schaus, S. E.; Jacobsen, E. N. Org. Lett. 2000, 2, 1001. See also Ref 9a.
23. Kobayashi, S.; Wakabayashi, T.; Nagayama, S.; Oyamada, H. Tetrahedron Lett. 1997, 38, 4559.

24. For effects of water in $\mathrm{Ln}(\mathrm{OTf})_{3}$-catalyzed aldol reactions, see: Ref. 3c.

25. Although the mechanism has not been fully elucidated, Yamamoto et al. have reported that addition of a catalytic amount of triphenylphosphine improves yields of the products in AgOTf-catalyzed allylation of benzaldehyde with allyltributyltin in aqueous THF: Yanagisawa, A.; Nakashima, H.; Ishiba, A.; Yamamoto, H. J. Am. Chem. Soc. 1996, 118, 4723.

26. a) Drew, M. G. B.; Nicholson, D. G.; Sylte, I.; Vasudevan, A. K. Acta Chem. Scand. 1992, 46, 396; b) von Arnim, H.; Dehnicke, K.; Maczek, K.; Fenske, D. Z. Anorg. Allg. Chem. 1993, 619, 1704; c) Simonov, Y. A.; Kravtsov, V. K.; Fonar', M. S.; Nazarenko, A. Y. Russian J. Inorg. Chem. 1996, 41, 371.

27. One of two bonds between $\mathrm{Pb}$ and the oxygens connected to the naphthalene rings is longer.

28. The reaction of benzaldehyde with $\mathbf{2}$ in the presence of $\operatorname{Pr}\left(\mathrm{NO}_{3}\right)_{3}(20 \mathrm{~mol} \%)$ and $\mathbf{1}(24 \mathrm{~mol} \%)$ in water/ ethanol (1/9) at $0{ }^{\circ} \mathrm{C}$ for $18 \mathrm{~h}$ afforded the aldol adduct in $59 \%$ yield with $76 \%$ de and $69 \%$ ee (syn).

29. The complex of 2,3,11,12-tetramethyl-18-crown-6 and $\mathrm{Ca}\left(\mathrm{NO}_{3}\right)_{2}$ or $\mathrm{KSCN}$ adopts similar conformation. a) Dyer, R. B.; Metcalf, D. H.; Ghirardelli, R. G.; Palmer, R. A.; Holt, E. M. J. Am. Chem. Soc. 1986, 108, 3621; b) Aoki, S.; Sasaki, S.; Koga, K. Tetrahedron Lett. 1989, 30, 7229.

30. Recently, complexes of lanthanide triflates with achiral polyethers were prepared and used in allylation and Diels-Alder reactions in dry dichloromethane: Aspinall, H. C.; Dwyer, J. L. M.; Greeves, N.; McIver, E. G.; Woolley, J. C. Organometallics 1998, 17, 1884.

Received: June 11, 2001 Published on the web: August 15, 2001 